FEATURE

Martin Kellaway

Office for National Statistics

\title{
Private Finance Initiative and public debt
}

n July last year, an influential British newspaper ran a front page report explaining the prospects for spending for public sector infrastructure projects. It concluded that the implementation of International Financial Reporting Standards (IFRS) in government financial reporting, which it anticipated would bring assets on balance sheet, would lead to the Government breaking one of its fiscal rules. The sustainable investment rule limits public sector net debt to 40 per cent of gross domestic product (GDP) and the report indicated that bringing on 'as much as $£ 30$ billion in off-balance sheet leases' would break this rule.

However, the introduction of IFRS will not lead to any changes in public sector net debt. This is a complicated area, which is not widely understood, and the newspaper was far from alone in drawing the conclusions it had. This article explains what is happening.

First of all it is necessary to appreciate that National Accounts, which are produced by the Office for National Statistics (ONS), and the commercial accounting profession use different accounting standards, which are designed and used for different purposes. The National Accounts present a historic record of activities in an economy, showing transactions between sectors of the economy when they happen, or accrue, with every transaction generating an equal and opposite entry for the parties involved. They do not attempt to show the financial position or income generation of single entities, nor to show future uncertain events such as provisions and contingent liabilities.

Despite the differences, one area where UK generally accepted accounting principles (GAAP) and the National Accounts system do have a similar approach is in deciding whether a lease is operating or financial - an important factor when accounting for Public Private Partnership (PPP) and Private Finance Initiative (PFI) type deals.

Consequently, ONS took advantage of this similarity in designing a pragmatic approach to produce its first public sector finance lease statistics for inclusion in public sector net debt. This pragmatic approach relies on the accounting judgements taken by the public sector entities involved, in conjunction with their auditors and according to the financial reporting standards they use, to determine whether an asset should be on or off the public sector balance sheet. Generally, an on balance sheet deal is recorded as a public sector finance lease and an off balance sheet deal is not - it is recorded as an operating lease.

With over 700 PPP/PFI deals in the UK, there was little alternative to this pragmatic approach if a long delay in producing estimates was to be avoided.

The approach was based on two assumptions: that it would produce consistent results across the economy (that is, there should be consistent recording in the National Accounts for both partners) and that it was compliant with European Union (EU) statistical rules for reporting government debt. The EU guidance here 
states that a GAAP approach is likely to produce similar results to the statistical approach.

In 2006, ONS produced its first estimates of imputed public sector finance leasing debt for inclusion in public sector net debt. The first estimates added almost $£ 5$ billion onto public sector net debt as at end-March 2006, equivalent to 0.4 per cent of GDP at that time. The black line in Figure 1 shows how this has been rising over time.

The finance leasing debt is, however, not the only contribution that PPP/PFI makes to public sector net debt. In two of the largest schemes, the London Underground PPP and the Channel Tunnel Rail Link, the privately-owned companies are subject to sufficient controls that ONS classifies them in the public sector for National Accounts purposes. The red line in Figure 1 shows the contribution to public sector net debt when the liabilities of these companies are included, which is substantially higher. The steep increase from 2002/03 reflects debt raised to finance both of these projects. The unitary payments for off balance sheet deals will also have an impact on public sector net debt at the time the cash is paid, but as this is a secondary effect, it has not been included in the graph.

The next phase of ONS's work in this area will revisit the pragmatic approach and test both the assumptions used in it. There are known to be examples of both off-off recording (where neither partners' accountants record the asset on their entity's balance sheet) and on-on recording (where both partners do). Neither of these is an acceptable outcome for a statistical system that requires recognition of just one such asset within the economy. The ONS work will be the most comprehensive investigation taken yet into the extent of this issue. Additionally, some PFI deals will be analysed using the European statistical rules in order to test the second assumption.

A new dimension that has been introduced is the transition to IFRS in government financial reporting. As IFRS implementation will involve public sector accountants using a different standard to that currently used, in particular if the International Financial Reporting Interpretations Committee (IFRIC) 12 interpretation is applied to the public sector partner in PPP/PFI deals, it could lead to different results in the financial statements of public sector entities. It is too early to judge what effect, if any, IFRS will have. One member of the Government's Financial Reporting Advisory Board is quoted as saying 'While it remains anyone's guess how much will be on the balance sheet, there is a pretty strong expectation that it is going to be a lot - most of it'. Others have suggested there will be little effect.

However, the important message here is that public sector net debt is a statistic that is derived from the National Accounts framework and not from IFRS. The European statistical rules, which concentrate on an evaluation of risks, have a different approach to IFRIC12, which focuses on control of the asset during the concession period, regulation of services, and what happens at the end of the concession period. Hence, any impact from IFRS in the financial statements of public sector entities will not automatically transfer into public sector net debt.

One possible implication of the move to IFRS for ONS is that, should the assumptions in the current pragmatic approach be confirmed as acceptable and if IFRS as implemented in the public sector produced different results, it would result in the loss of ONS's data source as the public sector reporting would have moved onto an incompatible basis.

\section{CONTACT}

elmr@ons.gsi.gov.uk

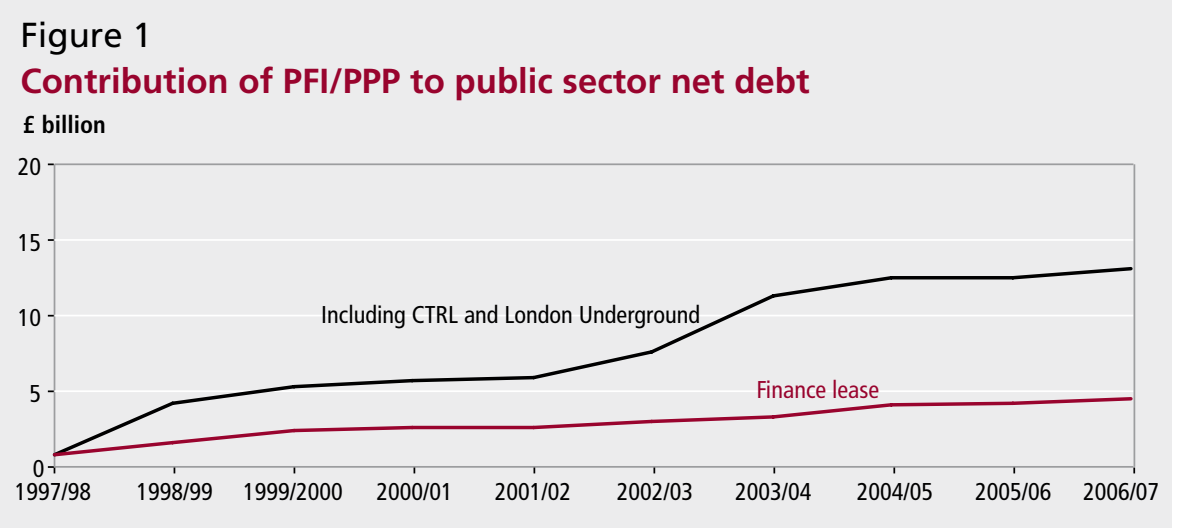

